\title{
The Effect of Gentamicin Nephrotoxicity in Newborn Mice at Breastfeeding
}

\author{
El Efecto de la Nefrotoxicidad por Gentamicina en Ratones Recién Nacidos Durante la Lactancia
}

\author{
Sajjad Hejazi' ${ }^{1}$ Mehran Kasebzadeh $^{2}$ \& Alireza Tagdisi $^{2}$
}

HEJAZI, S.; KASEBZADEH, M. \& TAGDISI, A. The effect of gentamicin nephrotoxicity in newborn mice at breastfeeding. Int. J. Morphol., 36(2):563-568, 2018.

SUMMARY: Gentamicin can pass through the placenta. This antibiotic also enters breast milk, but its absorption in the intestine is insignificant, so that it could be only found in half of the infants' blood. In the present study, it is attempted to experimentally evaluate the toxic effect of gentamicin on the kidneys of newborn mice in breastfeeding. This study was performed on 20 female Balb/c pregnant mice weighing 30 to $35 \mathrm{~g}$. The female pregnant mice were randomly divided to two groups of 10 . The lactating mothers were intraperitoneally injected with gentamicin at $200 \mathrm{mg} / \mathrm{kg}$ every other day sequentially, and the normal group was injected with normal saline at the same volume. Blod samples were collected from the heart of the newborns for the evaluation of renal function. The samples were passing paraffin blocks and were staining with hematoxylin and eosin. The data were expressed as mean $\pm \mathrm{SE}$ and T-test was used. In the observations of kidney tissues of the newborns treated with gentamicin, there were several tissue injuries in comparison with the normal group such as lytic necrosis with picnotic nucleus occurred in the epithelium cells of kidney tubules. Moreover, in some epithelium cells of tubules, degeneration changes of the kind of hydropic and cytoplasmic vacuolation were observed. In the current study, though gentamicin had no significant effect on anomalies in newborns. it indicated however, that the intervention breastfeeding could have pathological effects and consequently, cause changes in the function factors of the kidneys of newborns.

KEY WORDS: Breastfeeding; Gentamicin; Newborn Mice.

\section{INTRODUCTION}

Aminoglycoside antibiotics such as gentamicin are frequently used due to their high effectiveness against infections caused by gram negative bacteria (MartínezSalgado et al., 2007; Derakhshanfar et al., 2009). Many of the drugs or chemicals in the environment cause poisoning: This is often followed by tissue damage to the kidneys, which ultimately causes renal failure. The destruction of the tubule epithelium cells or tubular necrosis is one of the causes of acute renal failure.

However, it seems that the pathology of gentamicin in the kidneys by producing free radicals, lipid peroxidation (Sener et al., 2002) and protein peroxidation in the kidney cortical part (Karadeniz et al., 2008) is justifiable. Gentamicin can pass through the placenta, as reported in several separate studies; its amount in the umbilical cord blood has been found to be $34 \%$ and in mother's blood to be $42 \%$ (Santschi \& Papich, 2000). This antibiotic also enters breast milk, but its absorption in the intestine is insignificant: hence, it is found only in half of the infant's blood. It has also been demonstrated in some researches that pathologic damage to the kidney tissue ultimately leads to kidney bleeding, which afterward causes reduction in necessary proteins in the blood of the fetus and infant and in breast milk. In addition to proteins, other essential nutrients of blood as well as breast milk also get reduced, and hence the fetus and infant do not grow sufficiently (Brzóska et al., 2002). Accordingly, the present study attempts to experimentally evaluate the toxic effect of gentamicin in the kidneys of newborn mice undergoing breastfeeding.

\section{MATERIAL AND METHOD}

This experimental study was performed on 20 (12week-old) female Balb/c pregnant mice weighing 30 to $35 \mathrm{~g}$ sourced from the Laboratory Animal Breeding Center of Islamic Azad University. All ethical considerations and working protocols on laboratory animals were approved by

\footnotetext{
${ }^{1}$ Department of Anatomy, Tabriz branch, Islamic Azad University, Tabriz, Iran.

${ }^{2}$ Graduate of Veterinary Medicine, Tabriz branch, Islamic Azad University, Tabriz, Iran.
} 
the Animal Rights Monitoring Committee of the Research Center of the Faculty of Veterinary Medicine, Islamic Azad University, Tabriz Branch. No experiments were performed on the mice for one week in order to avoid stress and adapt animals to the new environment. Animals were stored in an environment with a temperature of $22 \pm 2{ }^{\circ} \mathrm{C}$, humidity of 38 $\%$, light intensity of 300 lux in the center of the room, and 12 $\mathrm{h}$ periods of light and darkness. Sufficient water and food (concentrated) were available to the animals. The female pregnant mice were randomly divided into two groups of 10 each. After the birth of newborns in the intervention group, lactating mothers were intraperitoneally injected with gentamicin (made by the Eksir Company, Iran) at $200 \mathrm{mg} / \mathrm{kg}$ (Chen et al., 2012) every other day sequentially from the first day to the end of the lactation period (about 21 days). Mothers in the normal group were injected with normal saline of the same volume. One day after the last intraperitoneal injection (day 21 of breastfeeding), blood samples were collected from the heart of the newborns for the evaluation of renal function. Serum urea density and uric acid were evaluated by the Berthold method (Patton \& Crouch, 1977) and creatinine was evaluated by the Jaffe method (Jafffe, 1886), using light metering by spectrophotometer device (Sinco) with the help of specially provided kits (Pars Azmoon Company).

The mice were anesthetized with chloroform and dissected after the experiments. Thereafter, the kidneys were weighed on a scale with a sensitivity of 0.01 (WTB model manufactured by Poland's Radwag company) and were measured by a caliper of $0.1 \mathrm{~mm}$ accuracy. The samples were put in a $10 \%$ buffer formalin solution, and 6-mm thick paraffin blocks were colored with the general method of hematoxylin and eosin (H\&E) after passing the autotechnicom steps (Bancroft \& Gamble, 2008). Histomorphometry variables of the diameter of the proximal and distal tubules and the height of the epithelium cells of proximal and distal tubules with the same cross-section were measured underneath a Nikon optical microscope (E200 Eclipse made in Japan) having a linear gradient and a $40 \times$ lens.

The data was expressed as mean $\pm \mathrm{SE}$; t -test was used to analyze the data using SPSS 16 software to compare the difference between the normal groups and the gentamicin groups. The value of $\mathrm{p}<0.05$ was considered for determining significance level between the groups.

\section{RESULTS}

\section{Biochemical results}

Effects on serum urea level. The results in Table I display a significant difference in mean serum urea level between the normal newborn group and the gentamicin treated group: the treated group had an increase in urea levels.

Effects on serum uric acid levels. The results in Table I display a significant difference in mean serum uric acid level between the normal newborns group and the gentamicin treated group: the treated group had an increase in uric acid levels.

Effects on serum creatinine level. The results in Table I display a significant difference in mean serum creatinine level between the normal newborns group and the gentamicin treated group: the treated group had an increase in creatinine levels.

\section{Morphometric results}

Kidney weight. The results in Table II demonstrate there is no significant difference in mean weight of the left kidney between groups of normal and gentamicin treated newborns.

Kidney length. The results in Table II demonstrate there is no significant difference in mean length of the right kidney between groups of normal and gentamicin treated newborns.

\section{Histomorphometric study}

Diameter of proximal tubules. The results in Table III indicate there is no significant difference in the mean diameter of proximal tubules between groups of normal and gentamicin treated newborns.

Diameter of distal tubules. The results in Table III indicate there is no significant difference in the mean diameter of distal tubules between groups of normal and gentamicin treated newborns.

The height of epithelium cells of proximal tubules. The results in Table III indicate there is no significant difference in the mean height of epithelium cells of proximal tubules between groups of normal and gentamicin treated newborns.

The height of epithelium cells of distal tubules. The results in Table III indicate there is no significant difference in the mean height of epithelium cells of distal tubules between groups of normal and gentamicin treated newborns.

Histopathologic results. Several tissue injuries were noticed in kidney tissues of the newborns treated with gentamicin as compared to the normal group. (Fig. 1A). Some epithelium cells of tubules, degeneration changes of the kind of hydropic changes, cytoplasmic vacuolation and also dilated glomerular capsule were observed (Fig. 1B).Tubular acute coagulant 

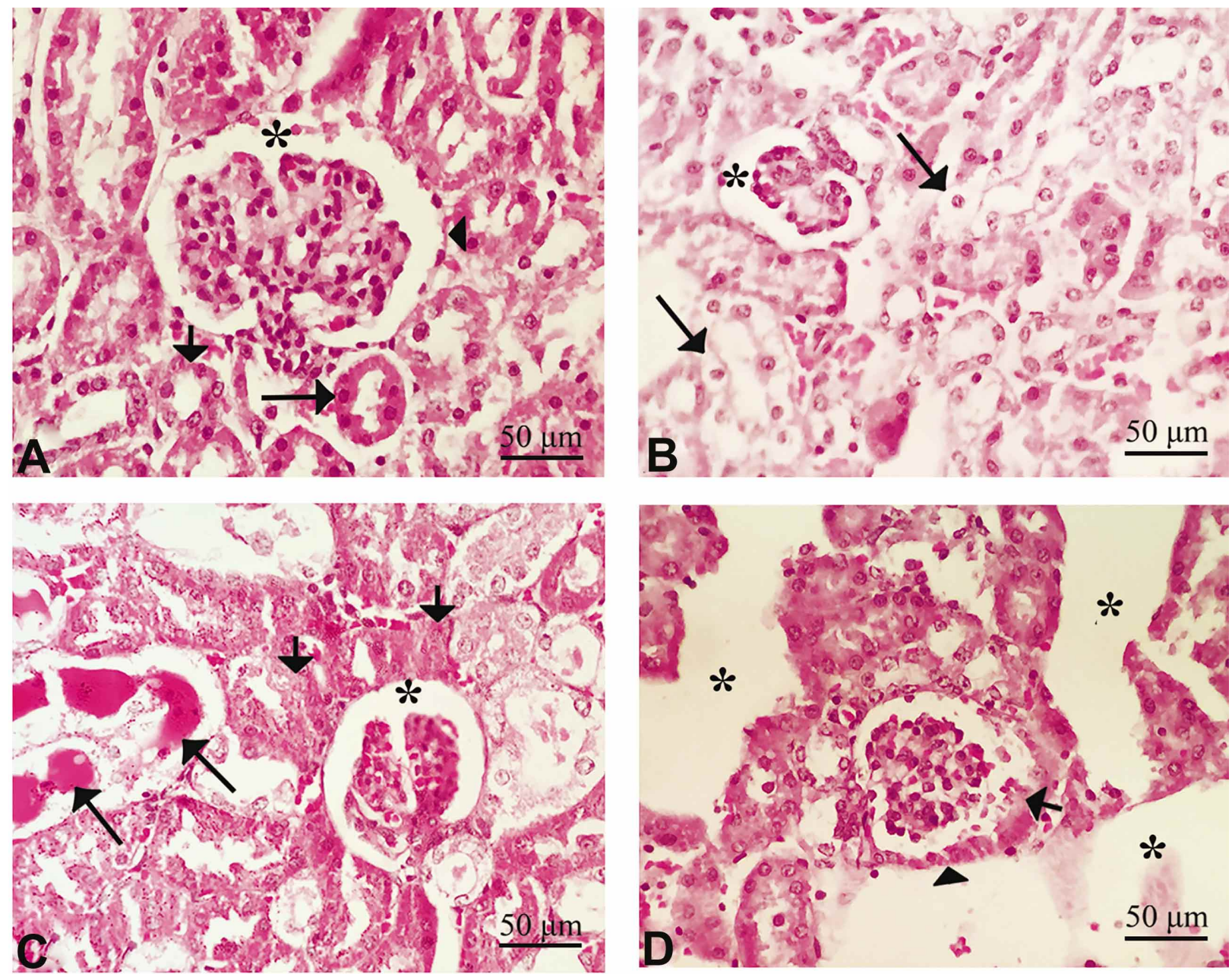

Fig. 1. Histological structure of the renal cortex of newborns mice as revealed by H\&E staining, scale bar $=50 \mu \mathrm{m}$. A. Normal group: capsular space (star), proximal convoluted tubule (arrow), distal convoluted tubule (short arrow), parietal epithelial cells of glomerular capsule (tip of arrow). B. Treatment group: Dilated glomerular capsule (star), Hydropic changes in tubular epithelial cells (arrow). C. Treatment group: Dilated glomerular capsule (star), Tubular acute coagulant necrosis (arrow). D. Treatment group: Edema in renal interstitial spaces (star), necrosis in simple squamous cell of glomerular capsule (tip of arrow), rupture in parietal cells of glomerular capsule (short arrow).

Table I. Comparison of mean serum level parameters (Mean \pm SD) of renal function factors in the normal newborn group and the gentamicin treated group.

\begin{tabular}{lrc}
\hline Content & Normal group $(\mathrm{n}=10)$ & Treatment group $(\mathrm{n}=10)$ \\
\hline Urea $(\mathrm{mg} / \mathrm{dl})$ & $38.55 \pm 1.369^{\mathrm{b}}$ & $49.6 \pm 2.424^{\mathrm{a}}$ \\
Creatinine $(\mathrm{mg} / \mathrm{dl})$ & $1.34 \pm 0.636^{\mathrm{b}}$ & $2.84 \pm 0.748^{\mathrm{a}}$ \\
Uric acid $(\mathrm{mg} / \mathrm{dl})$ & $4.18 \pm 0.328^{\mathrm{b}}$ & $5.23 \pm 0.25^{\mathrm{a}}$
\end{tabular}

The different letters in each column indicate a significant difference.

Table II. Comparison of mean kidney weight and length parameters (Mean SD) in groups of normal newborns and groups of newborns treated with gentamicin.

\begin{tabular}{lcc}
\hline Content & Normal group $(\mathrm{n}=10)$ & Treatment group $(\mathrm{n}=10)$ \\
\hline Weight of rt. kidney $(\mathrm{g})$ & $0.052 \pm 0.015^{\mathrm{b}}$ & $0.055 \pm 0.027^{\mathrm{a}}$ \\
Weigh of lt. kidney $(\mathrm{g})$ & $0.05 \pm 0.02 \mathrm{a}^{\mathrm{b}}$ & $0.061 \pm 0.021 \mathrm{a}$ \\
Length of rt. kidney $(\mathrm{mm})$ & $6.73 \pm 0.389 \mathrm{a}^{\mathrm{b}}$ & $7.015 \pm 0.137 \mathrm{a}$ \\
Length of lt. kidney $(\mathrm{mm})$ & $7.157 \pm 0.2^{\mathrm{ab}}$ & $7.54 \pm 0.349 \mathrm{a}$
\end{tabular}

The different letters in each column indicate a significant difference. 
necrosis with picnotic nucleus occurred in the epithelium cells of kidney tubules (Fig. 1C). Changes observed in the glomerular capsules were associated with necrosis in simple squamous cell (parietal layer) and after which rupture in parietal cells of glomerular capsule and leakage into glomerular urinary space was demonstrated. Renal interstitial edema in treated with gentamicin some of the other pathological observations of the present study (Fig. 1D).

Table III. Comparison of mean diameter parameters (Mean \pm SD) of proximal and distal tubules and the height of epithelium cells of proximal and distal tubules of kidney tissue in the groups of normal newborns and groups of newborns treated with gentamicin.

\begin{tabular}{lcc}
\hline Content & Normal group $(\mathbf{n}=\mathbf{1 0})$ & Treatment group $(\mathbf{n = 1 0})$ \\
\hline Diameter of PCT $(\mu \mathrm{m})$ & $30.16 \pm 0.828 \mathrm{a}^{\mathrm{b}}$ & $30.85 \pm 0.595 \mathrm{a}$ \\
Diameter of DCT $(\mu \mathrm{m})$ & $25.5 \pm 0.658 \mathrm{a}^{\mathrm{b}}$ & $24.47 \pm 0.37^{\mathrm{a}}$ \\
High of epithelial cell PCT $(\mu \mathrm{m})$ & $10.83 \pm 0.211 \mathrm{a}^{\mathrm{b}}$ & $10.58 \pm 0.172 \mathrm{a}$ \\
High of epithelial cell of DCT $(\mu \mathrm{m})$ & $6.37 \pm 0.39^{\mathrm{ab}}$ & $6.04 \pm 0.318 \mathrm{a}$ \\
\hline
\end{tabular}

The different letters in each column indicate a significant difference.

\section{DISCUSSION}

The prevalence of nephrotoxicity due to the use of gentamicin has risen from $3 \%$ in 1969 to $20 \%$ over the past decade. According to new results, about $30 \%$ of the people treated with gentamicin for more than seven days show some signs of nephrotoxicity. Use of medicines is limited due to their side effects, notwithstanding all the benefits (Derakhshanfar et al.). In this study, a significant increase in the concentration of renal function markers was observed when the test animals were treated with gentamicin in the lactation period. Several studies have been conducted to investigate the possibility of teratogenicity of gentamicin. In a study by Wing et al. (1998), infants with congenital diseases were compared with healthy ones, but there was no correlation between these disorders and gentamicin consumption. The results of this study did not relate death and external anomalies to the presence of gentamicin in the milk fed to newborn mice. The results obtained from the morphometric section of the kidneys indicate that the weight and length of kidney variables experience no significant difference in the newborns fed the milk of mothers under the effect of gentamicin. This can be attributed to the amount of gentamicin permeation in breast milk or to the duration of breastfeeding, reaching the point where breastfeeding under the effect of gentamicin does not make significant macroscopic changes. Additionally, significant differences in the histomorphometric variables of nephrons such as the height of the epithelium cells of distal and proximal tubules and the diameter of distal and proximal tubules in the newborns fed by mothers under the effect of gentamicin were not observed in the present study. This can be related to the amount of gentamicin permeation in mother's milk or to the period of breast feeding. Different methods such as measuring urea level, serum creatinine, and glomerular infiltration rate have been proposed to diagnose renal toxicity (Lau, 1999). According to some reports on nephrotoxicity caused by gentamicin, increase of serum creatinine and urea (Stojiljkovic et al., 2012; Li et al., 2013; Hsu et al., 2014) as well as decrease in glomerular filtration rate has been observed (Parlakpinar et al., 2005). Gentamicin also increases the plasma creatinine concentration (Derakhshanfar et al.; Yaman \& Balikci, 2010; Hsu et al.). The results of the present study are consistent with these reports. From the results of this study, a significant increase in the biochemical factors in the blood of newborn mice fed by mothers under the effect of the medicine can be observed: this indicates the effectiveness of gentamicin on renal function factors. According to a report, increase in plasma creatinine might be due to the damage to the tubules, and decrease in glomerular infiltration due to occlusion of the tract by necrotic cells (Kadkhodaee et al., 2007). Some researchers believe that increase in free radicals such as oxygen reactive types, superoxide anions, hydrogen peroxide, and lipid peroxidation is effective in reducing the side effects of gentamicin (Chiu et al., 2006). It is possible that these changes are caused by the lipid peroxidation of free radicals (Zietse et al., 2009). In the present study, urea, creatinine, and uric acid were found to increase: this is similar to results from the studies by Alam et al. (2005). The results of the present study reinforce the data obtained from this study, and demonstrate that nephrotoxicity is caused by gentamicin. In recent studies, renal toxicity has been evaluated on the basis of histopathologic observations and morphometric studies of renal tissues. In the current study, presence of gentamicin in breast milk caused irreversible changes in the nephron tissues of newborns. Nephrotoxicity in the newborns of the treatment group could be detected from the degeneration of tubule cells, and necrosis of the parietal cells of the glomerular capsule and its rupture in the urinary space. Interstitial edema in the spaces of tubules of renal parenchyma tissue was also observed. Nephrotoxic effects 
on the kidney tissue of newborn mice could be related to the amount of permeation of medicine in the breast milk. Shanley \& Burke (1990) have reported the occurrence of tubule cell necrosis mechanism given gentamicin usage in the presence of vesicle canaliculi in these cells. This leads to greater antibiotic absorption during the pinocytosis phenomenon as compared to other parts of the tubule: thus, cell necrosis occurs mostly in proximal tubules. It has been stated in the study of Robbins \& Cotran (1981) that due to the high storage capacity of kidneys and their ability to compensate for biochemical changes, injection period of gentamicin has to be prolonged. However, this has to be done in high doses due to retention of the drug in the kidney: this causes cell necrosis, resulting in reduction of the amount of glomerular infiltration and reducing the tubule's re-absorption. Alum et al. (2005), stated in their study that oxidative stress plays a major role in the histopathologic lesions of gentamicin. Gentamicin, on one hand, increases the production of free radicals, but on the other it inhibits antioxidant enzymes.

Based on the findings of the present study, the presence of gentamicin nephrotoxicity in treated newborn mice which received gentamicin through milk can be confirmed. In any case, avoiding the use of this medicine as a treatment for infectious diseases in nursing mothers should be done with caution. Gentamicin had no significant effect on occurrence of anomalies and death rate or morphological changes in newborns fed on intervention milk. However, it can be indicated that intervention breastfeeding could have pathological effects on the tissues of nephrons and, consequently, cause changes in the function factors of the kidneys of newborns.

HEJAZI, S.; KASEBZADEH, M. \& TAGDISI, A. El efecto de la nefrotoxicidad por gentamicina en ratones recién nacidos durante la lactancia. Int. J. Morphol., 36(2):563-568, 2018.

RESUMEN: La gentamicina puede pasar a través de la placenta. Este antibiótico también ingresa en la leche materna, pero su absorción en el intestino es insignificante, por lo que solo se puede encontrar en la mitad de la sangre de los recién nacidos. En el presente estudio, se intentó evaluar experimentalmente el efecto tóxico de gentamicina en los riñones de ratones recién nacidos durante la lactancia. Este estudio se realizó en 20 hembras preñadas con un peso entre 30 y $35 \mathrm{~g}$. Las hembras lactantes se dividieron aleatoriamente en dos grupos de 10 animales. Las madres que amamantaron fueron tratadas con gentamicina $(200 \mathrm{mg} / \mathrm{kg}$, vía intraperitoneal), cada dos días secuencialmente, y al grupo normal se le inyectó solución salina normal en el mismo volumen. Se tomaron muestras de sangre del corazón de los recién nacidos para la evaluación de la función renal. Las muestras pasaron por bloques de parafina y se tiñeron con hematoxilina y eosina. Los datos se expresaron como media \pm DE y $t$-test. En comparación con el grupo normal, se observaron varias lesiones en los tejidos del ri- ñón de los ratones recién nacidos tratados con gentamicina, tal como como necrosis lítica con núcleo picnótico en las células del epitelio de los túbulos renales. Además, en algunas células del epitelio de los túbulos renales, se observaron cambios degenerativos del tipo de vacuolación hidrópica y citoplásmica. En el estudio actual, la gentamicina no tuvo un efecto significativo sobre las anomalías en los recién nacidos. Sin embargo, observamos que la intervención de amamantamiento podría tener efectos patológicos y, en consecuencia, causar cambios en los factores funcionales de los riñones en recién nacidos.

PALABRAS CLAVE: Lactancia; Gentamicina; Ratones recién nacidos.

\section{REFERENCES}

Alam, M. M.; Javed, K. \& Jafri, M. A. Effect of Rheum emodi (Revand Hindi) on renal functions in rats. J. Ethnopharmacol., 96(1-2):121-5, 2005.

Bancroft, J. D. \& Gamble, M. Theory and Practice in Histological Techniques. $6^{\text {th }}$ ed. Edinburgh, Churchill Livingstone, 2008.

Brzóska, M. M.; Moniuszko-Jakoniuk, J.; Jurczuk, M. \& Gaazyn-Sidorczuk, M. Cadmium turnover and changes of zinc and copper body status of rats continuously exposed to cadmium and ethanol. Alcohol Alcohol., 37(3):213-21, 2002.

Chen, L.; Xiong, S.; Liu, Y. \& Shang, X. Effect of different gentamicin dose on the plasticity of the ribbon synapses in cochlear inner hair cells of C57BL/6J mice. Mol. Neurobiol., 46(2):487-94, 2012.

Chiu, P. Y.; Leung, H. Y.; Poon, M. K. \& Ko, K. M. Chronic schisandrin B treatment improves mitochondrial antioxidant status and tissue heat shock protein production in various tissues of young adult and middle-aged rats. Biogerontology, 7(4):199-210, 2006.

Derakhshanfar, A.; Bidadkosh, A. \& Sadeghian, M. H. L-methionine attenuates gentamicin nephrotoxicity in male Wistar rat: pathological and biochemical findings. Iran. J. Vet. Res., 10(4):323-8, 2009.

Hsu, Y. H.; Chen, T. H.; Wu, M. Y.; Lin, Y. F.; Chen, W. L.; Cheng, T. H. \& Chen, C. H. Protective effects of Zhibai Dihuang Wan on renal tubular cells affected with gentamicin-induced apoptosis. J. Ethnopharmacol., 151(1):635-42, 2014.

Jaffe, M. Z. Ueber den Niederschlag, welchen Pikrinsäure in normalem Harn erzeugt and ueber eine Reaktion des Kreatinins. Zeit. Physiol. Chem., 10:391-400, 1886.

Kadkhodaee, M.; Khastar, H.; Arab, H. A.; Ghaznavi, R.; Zahmatkesh, M. \& Mahdavi-Mazdeh, M. Antioxidant vitamins preserve superoxide dismutase activities in gentamicin-induced nephrotoxicity. Transplant. Proc., 39(4):864-5, 2007.

Karadeniz, A.; Yildirim, A.; Simsek, N.; Kalkan, Y. \& Celebi, F. Spirulina platensis protects against gentamicin-induced nephrotoxicity in rats. Phytother. Res., 22(11):1506-10, 2008.

Lau, A. H. Apoptosis induced by cisplatin nephrotoxicity injury. Kidney Int., 56:1295-8, 1999.

Li, Y. C.; Shih, Y. M. \& Lee, J. A. Gentamicin caused renal injury deeply related to methylglyoxal and $\mathrm{N}(\varepsilon)$-(carboxyethyl)lysine (CEL). Toxicol. Lett., 219(1):85-92, 2013.

Martínez-Salgado, C.; López-Hernández, F. J. \& López-Novoa, J. M. Glomerular nephrotoxicity of aminoglycosides. Toxicol. Appl. Pharmacol., 223(1):86-98, 2007.

Parlakpinar, H.; Tasdemir, S.; Polat, A.; Bay-Karabulut, A.; Vardi, N.; Ucar, M. \& Acet, A. Protective role of caffeic acid phenethyl ester (cape) on gentamicin-induced acute renal toxicity in rats. Toxicology, 207(2):169$77,2005$. 
Patton, C. J. \& Crouch, S. R. Spectrophotometric and kinetics investigation of the Berthelot reaction for the determination of ammonia. Anal. Chem., 49(3):464-9, 1977.

Robbins, S. L. \& Cotran, R. S. Pathologic Basis of Disease. $2^{\text {nd }}$ ed. Philadelphia, Saunders, 1981.

Santschi, E. M. \& Papich, M. G. Pharmacokinetics of gentamicin in mares in late pregnancy and early lactation. J. Vet. Pharmacol. Ther., 23(6):359-63, 2000.

Sener, G.; Sehirli, A. O.; Altunbas, H. Z.; Ersoy, Y.; Paskaloglu, K.; Arbak, S. \& Ayanoglu-Dulger, G. Melatonin protects against gentamicininduced nephrotoxicity in rats. J. Pineal Res., 32(4):231-6, 2002.

Shanley, P. F. \& Burke, T. J. Differential susceptibility to gentamicin toxicity within the proximal convoluted tubule. Ren. Fail., 12(2): 83-7, 1990.

Stojiljkovic, N.; Stoiljkovic, M.; Randjelovic, P.; Veljkovic, S. \& Mihailovic, D. Cytoprotective effect of vitamin $C$ against gentamicin-induced acute kidney injury in rats. Exp. Toxicol. Pathol., 64(1-2):69-74, 2012.

Wing, D. A.; Hendershott, C. M.; Debuque, L. \& Millar, L. K. A randomized trial of three antibiotic regimens for the treatment of pyelonephritis in pregnancy. Obstet. Gynecol., 92(2):249-53, 1988.

Yaman, I. \& Balikci, E. Protective effects of nigella sativa against gentamicin-induced nephrotoxicity in rats. Exp. Toxicol. Pathol., 62(2): 183-90, 2010

Zietse, R.; Zoutendijk, R. \& Hoorn, E. J. Fluid, electrolyte and acid-base disorders associated with antibiotic therapy. Nat. Rev. Nephrol., 5(4):193-202, 2009
Corresponding author:

Sajjad Hejazi

Department of Anatomy

Tabriz Branch, Islamic Azad University

Tabriz

IRAN

\section{Email: sajjadhejazi1@gmail.com}

Received: 06-12-2017

Accepted: 29-01-2018 